\title{
The Impact of Herding on the Risk Pricing in the Egyptian Stock Exchange
}

\author{
Mustafa Hussein Abd-Alla ${ }^{1}$, Mahmoud Sobh ${ }^{2}$ \\ ${ }^{1}$ Sadat Academy for Management Sciences \\ Department of Business Administration \\ Cairo, Egypt \\ Email: m_haa60@yahoo.com \\ ${ }^{2}$ Ain Shams University \\ Faculty of Commerce \\ Cairo, Egypt
}

\begin{abstract}
We test the impact of herding behaviour on the risk pricing in the Egyptian Stock Exchange (EGX) by adding an additional risk factor reflecting herding behaviour to the Fama and French three-factor model. We construct a portfolio to mimic an additional risk factor related to herding behaviour, in addition to the original risk factors in the Fama and French three-factor model. The three-factor model will be tested in its original form and re-tested after adding the herding behaviour factor. The study is based on Hwang and Salmon methodology, in which the state space approach based on Kaman's filter was used to measure herding behaviour. We used monthly excess stock returns of 50 stocks listed on the EGX from January 2014 to December 2018. The results do not support Fama and French model before and after adding the herding behaviour factor, therefore, there is no effect of herding behaviour on the risk pricing in the Egyptian Stock Exchange.
\end{abstract}

Keywords: Fama and French Three-Factor Model, Herding Behaviour, State Space Model

JEL codes: G12, G41

\section{Introduction}

In the 1970s, there was a widespread belief that financial markets are efficient, investors are rational and the stock prices quickly adapt to new information and reflect all available information. The concept of the Efficient Market hypothesis presented by Fama (1970) attracted the attention of many scientists and researchers in the financial sciences, in an attempt to either support or challenge the Efficient Market principles (Fama and MacBeth 1973; Black, Jensen, and Scholes 1972; Jensen 1978).

In the 1970 s and 1980 s, the term of behavioural finance began to appear as an application of behavioural economics in financial markets; it became an alternative to classical theory. The concept of cognitive psychology was used to explain the behaviour of investors in financial markets. Many empirical researches have shown that market transactions often manifest clear anomalies and that investors make 
unreasonable decisions, which may lead to inaccurate asset pricing, in great contrast to traditional theories claiming the absolute rationality of investors (Rozeff and Kinney 1976; French 1980; Shiller 1980; Banz 1981; De Bondt and Thaler 1985; Basu 1983; Shefrin and Statman 1985; Ariel 1987; Lakonishok and Smidt 1988).

The field of financial modelling is one of the most important fields in the theory of modern finance, which examines the relationship between return and risk. The Capital Asset Pricing Model (CAPM), presented by Sharpe (1964) and Lintner (1965) and developed based on portfolio theory by Harry Markowitz (1952), is the first capital asset pricing model to explain the relationship between risk and return. However, there have been some studies that have called the CAPM asset pricing model invalid, which has led researchers in the financial sciences to find upgraded versions of the CAPM model (Black 1972; Ross 1976).

In 1992, Fama and French studied the ability of each the market beta coefficient, size of the firm, book-to-market equity ratio, leverage and Earnings/Price ratio $(E / P)$ to explain the expected return. The results indicated no relationship between the market beta factor and the stock returns, but there was a strong relationship between size and $B / M$ ratio and stock returns: a strong significant positive relationship between $B / M$ value and stock returns and a negative relation between size and stock returns.

Based on their previous results, Fama and French (1993) concluded that the variation in stock returns could be explained by the market beta coefficient, size of the firm, and book-to-market equity ratio. Accordingly, Fama and French constructed the three-factor model, which is used for explaining the variation in stock returns by employing these three factors as the explanatory variables.

The research is still ongoing in the field of financial modelling and risk pricing to our present time, especially after the major developments in the financial science, and the most important of these developments is the emergence of behavioural finance. In this study, we will be exposed to the field of behavioural finance as one of the most important fields of the modern finance, where investment behaviour has become one of the most important factors to take into account when talking about the topics of finance. It has a great impact on the pricing of capital assets. We will try to identify the impact of herding behaviour - as a behavioural financing factor - on the risk pricing in the Egyptian Stock Exchange (EGX) by adding an additional risk factor reflecting herding behaviour $\left(\boldsymbol{h}_{\boldsymbol{m} t}\right)$ to the three-factor model of Fama and French, where the Fama and French three-factor model (1993) will be tested in its original form and re-tested after adding the additional risk factor from January 2014 to December 2018, to know the effect of herding on the risk pricing in the Egyptian stock exchange.

The study will be organized as follows. In section 2 we will provide theoretical and empirical literature of the herding behaviour and the Fama and French three-factor model (1993). Section 3 presents the data and methodology. Section 4 presents empirical results, and finally, we will provide conclusions in a separate chapter. 


\section{Fama and French Three-factor Model}

\subsection{Theoretical Literature}

The Capital Asset Pricing Model (CAPM), developed by Sharpe (1964) and Lintner (1965), is based on the work of Harri Markowitz (1959), who developed the "mean-variance model". The CAPM model pointed out that there is a positive linear relationship between the expected risk of the asset and the expected rate of return. The only measure of risks is the systematic risk, which is measured through beta. However, the assumption of the CAPM that only systematic risk factors explain the expected return has led many researchers to criticize the model in an attempt to provide a model that is more able to explain the expected return.

In their study on the non-financial stocks listed on the NYSE, NASDAQ, and AMEX from 1963 to 1990, Fama and French (1992) examined the ability of the beta coefficient, book-to-market equity ratio, size of the firm, Earnings/Price ratio $(E / P)$, and leverage, to predict the stock returns. They concluded that there was no relationship between the market beta factor and the stock returns, they also found that small stocks and stocks with high book-to-market equity ratios (value stocks) have high returns compared to big stocks and stocks with low book-tomarket equity ratios (growth stocks).

Fama and French (1993) examined the relation between expected excess returns and the market premium as well as the size of the firm measured by market capitalization, which is calculated through the average return on the portfolios with small market capitalization stocks minus the average return on the portfolios with big market capitalization stocks, and the value of the firm measured by the bookto-market equity ratio, which is calculated through the average excess return on a portfolio with a high ratio of book-to-market stocks minus the average excess return on a portfolio with a low ratio of book-to-market stocks. They expanded the study to include the U.S government and corporate bonds in addition to stocks. They concluded that portfolios created based on the market factor, size and bookto-market-equity have important effects on stock returns, where Fama and French three-factor model (1993) is successful in the explanation of the cross-section of average returns on U.S. stocks. Their model can be written as:

$$
R_{i t}-R_{f}=b_{i}\left[R_{m t}-R_{f}\right]+s_{i}[S M B]+h_{i}[H M L]
$$

Where:

- $\quad R_{i t}$ is the expected return on asset $i$ at time $t$;

- $\quad R_{f}$ is the risk-free rate;

- $\quad b i, s i$, hi are the coefficients (betas) of the three independent variables $\mathrm{R}_{\mathrm{mt}}-$ $\mathrm{R}_{\mathrm{f}}, \mathrm{SMB}$ and $\mathrm{HML}$;

- $\quad R_{m t}-R_{f}$ is the expected excess return of the market portfolio at period $t$;

- HML is the expected return on the book-to-market value (BE/ME) factor (a proxy for firm value);

- $\quad$ SMB is the expected return of the size factor (a proxy for firm size). 


\subsection{Empirical Literature}

Canbaş and Arioğlu (2008) examined the ability of the Fama and French threefactor model (1993) to explain the cross-section of expected stock returns in the Istanbul Stock Exchange (ISE) from July 1993 to June 2004. They found that the Fama and French three-factor model (1993) was not able to explain the crosssection of expected stock returns in the Istanbul Stock Exchange.

Nartea et al. (2009) compared the performance of both the CAPM model and Fama and French three-factor model (1993) in the ability of each to explain the crosssectional variation in average stock returns in the New Zealand Stock Exchange from 1995 to 2004. They divided the sample into 6 portfolios based on size and value. The study concluded that the Fama and French three-factor model (1993) can explain the cross-sectional variation in average stock returns better than the CAPM model.

Simlai (2009) examined the ability of the Fama and French three-factor model (1993) to explain the cross-section of expected stock returns for a sample of all stocks in NYSE, AMEX, and NASDAQ from July 1926 to June 2007. The study concluded that the explanatory power of the size and value factor is very strong in explaining the stock return. Also, the average return for stocks with high BE / ME ratio is greater than the average return for stocks with lower $\mathrm{BE} / \mathrm{ME}$ ratio.

Rahmani and Salmani (2010) compared the performance of both the CAPM model and Fama and French three-factor model (1993) using monthly and annual data from 1999 to 2009 in the Tehran Stock Exchange. They divided the sample into 6 portfolios based on size and value. The study concluded that the explanatory power of the Fama and French three-factor model (1993) is higher than the CAPM model. At the same time, adding size and value factors to the CAPM improved its explanatory power

Taneja (2010) compared the performance of both the CAPM model and the Fama and French three-factor model (1993) using a sample of 187 stocks listed on the Indian Stock Exchange from June 2004 to June 2009. The study concluded that the explanatory power of the Fama and French three-factor model (1993) is higher than that of the CAPM model. At the same time, adding size and value factors to the CAPM improved its explanatory power.

Dolinar (2013) examined the ability of the Fama and French three-factor model (1993) to explain the cross-section of expected stock returns using monthly returns of a sample of 37 stocks listed on the Croatian Stock Exchange from April 2007 to March 2013. The study concluded that the Fama and French three-factor model (1993) can explain the cross-sectional variation in average stock returns.

Eraslan (2013) tested the validity of the Fama and French three-factor model (1993) using monthly data for a sample of 274 stocks listed on the Istanbul Stock Exchange (ISE) from January 2003 to December 2010. The study concluded that the explanatory power of Fama and French three-factor model (1993) is weak in explaining the cross-sectional differences in average returns. 
Sobt (2016) examined the performance of the CAPM and the Fama and French three-factor model (1993) in their ability to explain the cross-sectional differences in average return in the Indian stock market for a sample of 298 stocks listed in the S\&P CNX 500 index from October 2005 to March 2015. The study found that the systematic risk factor (beta) is not statistically significant. The results also showed that the explanatory power of the CAPM model is very weak, which indicates that other factors explain the cross-sectional differences in average returns other than the market factor. The study concluded that there was a significant improvement in the value of the $\left(R^{2}\right)$ coefficient when using the Fama and French three-factor model (1993).

Wang (2018) examined the ability of the Fama and French three-factor model (1993) to explain the cross-section of expected stock returns in the Taiwan stock market using monthly data from July 1982 to December 2012. He concluded that $\left(R^{2}\right)$ for the six portfolios ranged from $93 \%$ to $97 \%$, which indicates a great ability to explain the cross-section of expected stock returns.

\section{Herding Behaviour}

\subsection{Theoretical Literature}

Bikhchandani and Sharma (2001) defined herd behaviour as deliberate or inadvertent reproduction of the behaviour of other investors. The classical theory does not adequately address this aspect, as it supports the independence of investor decisions and assumes rational behaviour of investors. According to Hwang and Salmon (2004), herd behaviour arises when investors decide to mimic others' decisions in the market rather than follow their own beliefs and information. This means that the return on individual investments will move in the same direction as the market portfolio, which makes returns on individual investments very close to market returns, resulting in a lower degree of deviation from these returns.

Many researchers have measured herd behaviour within financial markets. Christie and Huang (1995) measured the herd behaviour in the market by observing how individual stock returns move against the return on the market portfolio. They proposed the Cross-Sectional Standard Deviation of Returns (CSSD) as a measure of dispersion to measure the herd behaviour in the market. Herd behaviour means that the return on individual stocks is approaching the return on the market. The study assumed that the investors neglected their beliefs and made the investment decision according to market consensus. The study applied the method of dispersion of return on the daily and monthly data of the New York Stock Exchange (NYSE) and AMEX from 1962 to 1988. This method failed to detect herd behaviour.

Chang et al. (2000) extended the work of Christie and Huang (1995) and developed a new method based on the Cross-Sectional Absolute Deviation of return (CSAD) in a nonlinear regression to examine the relation between the level of stock return dispersions and the market return. The study examined herd behaviour in some international stock markets and found that herd behaviour was not found in the 
developed markets such as the US and Hong Kong, but the results supported herd behaviour in the emerging markets such as South Korea and Taiwan.

Hwang and Salmon (2004) developed a different approach in their study of the US and South Korean markets. Their model is based on the Cross-Sectional Standard Deviation of the beta to test herding in UK, US, and South Korean stock markets. When investors have a behavioural bias and their decisions are not rational, their assessment of the relationship between return on assets and risk is distorted. Thus, if the herd behaviour is already found among investors in the market, the return on all investments moves in the same direction as the market portfolio, so CAPMbetas will deviate from their equilibrium values. They found herding behaviour in the stock market under normal market conditions rather than under market stress.

\subsection{Empirical Literature}

Demirer et al. (2010) tested herd behaviour in the Taiwan Stock Exchange from 1995 to 2006 in five sectors within the market. The study used the Christie and Huang model (CH) (1995), the Chang et al. (CCK) (2000), and Hwang and Salmon (HS) (2004) method to study herd behaviour. The study found that when using the $\mathrm{CH}$ model, no presence of herd behaviour was observed in all sectors, but when using the CCK model, the presence of herd behaviour was observed in the sectors, and when using the HS model the presence of herd behaviour was observed in all sectors.

Elkhaldi and Benabdelfatteh (2014) tested herd behaviour in the Tunisian Stock Exchange using daily data for a sample of 10 stocks from 3 June 2002 to 31 May 2013, by using Hwang and Salmon (2004) method. The study found evidence supporting herd behaviour among investors in the Tunisian stock market.

Demir et al. (2014) tested herd behaviour in the Istanbul Stock Exchange, using the daily stock prices of companies listed in the index BIST-100 from January 2000 to October 2011, and employing Hwang and Salmon (2004) method. The study found that herd behaviour is statistically significant in the Istanbul Stock Exchange. The study also found that the behaviour is due to the emotion and feelings of investors and not due to market conditions such as fluctuations in stock returns and fluctuations in market returns.

Messis and Zapranis (2014) investigated the presence of herd behaviour in the Athens Stock Exchange from February 1995 to April 2010. Herd behaviour was measured using the Hwang and Salmon (2004) model. The results showed that the herd behaviour was found during different periods of the study and that stocks manifested high levels of herd behaviour and high levels of volatility. The study also considered herd behaviour as an additional risk factor.

Güvercin (2016) investigated the presence of herd behaviour at both the Egyptian and Saudi stock markets. The study also aimed to assess the impact of regional and global shocks (such as the mortgage crisis, the political volatility that occurred on July 3, 2013, oil price fluctuations and the civil war) on herd behaviour at these 
markets. The herd behaviour was measured using Hwang and Salmon (2004) method. The study found that herd behaviour only exists within the Egyptian stock market, whereas there is no herd behaviour among investors in the Saudi stock market. The results also showed that the mortgage crisis and the political fluctuations that occurred on July 3, 2013, had a significant effect on herd behaviour, while oil revenues, oil price fluctuations and the Syrian conflict did not affect herd behaviour.

Metwally et al. (2016) investigated the presence of herd behaviour in the Egyptian stock market in the case of uptrend and downtrend of the market. The data used in their study consisted of daily closing prices, market returns, and interest rates as a risk-free rate of return, from January 2007 to December 2012. The study found that herd behaviour exists in the Egyptian stock market, where the results indicate that the returns of individual stocks have a low dispersion from market returns during the period of study. The study also found that the herd behaviour is stronger during periods of declining market returns (downtrend), while no evidence was found on the herd behaviour during the volatility of the market. The study also pointed to the absence of any evidence of the herd behaviour among investors in the uptrend case.

Mertzanis and Allam (2018) investigated the presence of herd behaviour in the Egyptian stock market from January 2003 to April 2014. The study also investigated the presence of herd behaviour during the pre- and post-2011 revolution period. The study did not find any evidence supporting herd behaviour during the whole period. The study provided weak evidence of the presence of herd behaviour during the pre- and post-2011 revolution period.

\section{Data and Methodology}

\subsection{Data}

The Egyptian Stock Exchange dates back to the 19th century, as the Alexandria Stock Exchange was established in 1883, and the Cairo Stock Exchange was established in 1903. Thus, The Egyptian Stock Exchange is considered one of the oldest stock exchanges in the Middle East. The number of companies listed on the Egyptian Stock Exchange at the end of 2018 reached 256 companies $^{1}$. The study used daily, monthly and annual data for a sample of firms listed on the EGX from January 2014 to December 2018 to test the Fama and French three-factor model (1993) in its original form and re-tested the after adding the herding as an additional risk factor, in order to detect the effect of herding on the risk pricing in the Egyptian Stock Exchange. These data included monthly returns for individual stocks and EGX100 index. EGX100 measures the performance of 100 active companies in the Egyptian Stock Exchange, including both 30 companies of EGX 30 Index and 70 companies of EGX 70 Index. We used EGX100 index returns as a proxy for the market portfolio returns; we used monthly returns on the postal savings as a proxy for the risk-free rate. Annual financial statements are used for

\footnotetext{
${ }^{1}$ http://www.egx.com.eg
} 
extracting data on book values of equity and we calculated the monthly beta values for each stock in the sample.

Not all stocks are chosen for testing the models; we followed a set of criteria for selecting sample stocks, as follows:

- Stocks should be listed on the EGX100 index.

- Exclude stocks that are traded in currencies other than the Egyptian pound.

- Exclude stocks of banks and financial institutions.

- $\quad$ Stock prices should be available for 60 continuous months.

- The book-to-market ratio should be positive.

By applying these conditions, we got a sample of 50 stocks listed on the EGX100 index in the Egyptian Stock Exchange.

\subsection{Methodology}

To mimic the common risk factors of size and book-to-market equity, we used the Fama and French (1993) approach to construct six portfolios sorted according to market capitalization and book-to-market equity. Fama and French form size and book-to-market equity portfolios to describe the cross-sectional variation in the average stock rate of returns. The state-space model used by Hwang and Salmon (2004) was used to measure herd behaviour.

\section{Herding Behaviour Measurement}

At fist, we obtained 60 monthly beta estimates for each stock. We estimated beta coefficients using the OLS method, based on daily observations of each month, as follows:

$$
r_{i t}=\alpha_{i t}^{b}+\beta_{i m t}^{b} r_{m t d}+\varepsilon_{i t d}
$$

where $r_{i t d}$ is the excess returns; $r_{m t d}$ is the excess market returns and $t d$ refers to the daily data for the month $(t)$.

Individual stocks returns are calculated as follows:

$$
R_{i t}=\frac{\left(P_{t}-P_{t-1}\right)}{P_{t-1}}
$$

Where $P_{t}$ is the closing price of the stock (i) at the time (t).

To test herding behaviour, the study employs Hwang and Salmon (2004) method from their study on the US and South Korean markets, which is based on the crosssectional volatility of beta coefficients. Hwang and Salmon (2004) method is based on the relationship between the equilibrium beta $\left(\beta_{i m t}\right)$ and its behaviourally biased equivalent $\left(\beta_{i m t}^{b}\right)$ as follows:

$$
\frac{E_{t}^{b}\left(r_{i t}\right)}{E_{t}\left(r_{m t}\right)}=\beta_{i m t}^{b}=\beta_{i m t}-h_{m t}\left(\beta_{i m t}-1\right)
$$


Where $E_{t}^{b}\left(r_{i t}\right)$ is the biased expected returns on the asset $\mathrm{i}$ at time $\mathrm{t}$ and $\beta_{i m t}^{b}$ is a measure of systematic risk. $E_{t}\left(r_{m t}\right)$ is the conditional expectation of the market excess returns at time t. $h_{m t}$ is the latent herding behaviour parameter changing over time. When $h_{m t}=0$, this indicates that there is no herding behaviour. When $h_{m t}=1$, this indicates that there is perfect herding behaviour towards market portfolio, meaning that all the individual stocks change following the market portfolio movements. However, when $0<h_{m t}<1$, this indicates the presence of herding behaviour depending on the degree of $h_{m t}$. For measuring herding behaviour on a market-wide basis, the cross-sectional variation of $\beta_{i m t}^{b}$ is calculated as follows:

$$
\operatorname{Std}_{c}\left(\beta_{i m t}^{b}\right)=\operatorname{Std}_{c}\left(\beta_{i m t}\right)\left(1-h_{m t}\right)
$$

And when taking logarithms on both sides of equation (4) we get:

$$
\log \left[\operatorname{Std}_{c}\left(\beta_{i m t}^{b}\right)\right]=\log \left[\operatorname{Std}\left(\beta_{i m t}\right)\right]+\log \left(1-h_{m t}\right)
$$

Equation (5) may be rewritten as:

Where

$$
\log \left[\operatorname{Std}_{c}\left(\beta_{\text {imt }}\right)\right]=\mu_{m}+v_{m t}
$$

With

$$
\begin{gathered}
\mu_{m}=E\left[\log \left[\operatorname{Std} d_{c}\left(\beta_{i m t}\right)\right]\right] \text { and } v_{m t} \sim \operatorname{iid}\left(0, \sigma_{m, v}^{2}\right) \\
H_{m t}=\log \left(1-h_{m t}\right)
\end{gathered}
$$

Hwang and Salmon (2004) suggested that $H_{m t}$ follows an AR(1) process, which will be estimated using the Kalman filter:

$$
\begin{array}{r}
\log \left[\operatorname{Std} d_{c}\left(\beta_{i m t}^{b}\right)\right]=\mu_{m}+H_{m t}+v_{m t} \\
H_{m t}=\varphi_{m} H_{m, t-1}+\eta_{m t}
\end{array}
$$

Where $\eta_{m t} \sim$ iid $\left(0, \sigma_{m, \eta}^{2}\right)$.

The Log $\left[\operatorname{Std}_{c}\left(\beta_{i m t}^{b}\right)\right]$ is expected to change with herding. A significant value of the variance of the error term $\eta_{m t}\left(\sigma_{m, \eta}^{2}\right)$ refers to the existence of herding behaviour and a significant of the persistence parameter $\left(\varphi_{m}\right)$ supports this observation. Furthermore, the $\varphi$ must be stationary, i.e., $|\varphi| \leq 1$. 
The cross-sectional standard deviation of betas for each month is calculated by the following equation:

$$
\left.\operatorname{Std}_{c}(\beta)_{t}\right)=\sqrt{\frac{\sum_{i-1}^{n}\left(\text { beta }_{i t}-\overline{\text { beta }_{t}}\right.}{n-1}}
$$

\section{Portfolios Construction}

To construct the SMB (Small minus Big) and HML (High minus Low) factors, the Fama and French (1993) methodology was used, where all stocks in the sample were ranked based on market capitalization in June of each year $t$. Then the stocks are sorted into two portfolios using the median sample size (Big (B) and Small (S)) according to split point which is $50 \%$, where the highest $50 \%$ stocks are big and the lowest $50 \%$ stocks are small. The sample is also ranked by book-tomarket equity ratio, where the stocks are divided into three portfolios according to book-to-market equity ratio. The first portfolio, $30 \%$ of whole sample stocks, has highest book-to-market equity ratio (High: H group). The second portfolio, $40 \%$ of whole sample stocks, has medium book-to-market equity ratio (Medium: M group); and the third portfolio, $30 \%$ of whole sample stocks, has the lowest book-to-market equity ratio (Low: L group).

Based on the intersection of the tow size and three $\mathrm{BE} / \mathrm{ME}$ portfolios, we constructed six portfolios (BL, BM, BH, SL, SM, SH) where:

- $\quad \mathrm{SH}$ is the portfolio with small-cap and high book-to-market stocks;

- $\quad$ SM is the portfolio with small-cap and medium book-to-market stocks;

- $\quad$ SL is the portfolio with small-cap and low book-to-market stocks;

- $\quad \mathrm{BH}$ is the portfolio with big-cap and high book-to-market stocks;

- $\quad B M$ is the portfolio with big-cap and medium book-to-market stocks;

- $\quad B L$ is the portfolio with big-cap and low book-to-market stocks.

SMB (small minus big) is the difference between returns on a small-cap stocks portfolio and on a big-cap stocks portfolio, and is calculated by the following equation:

$$
S M B=[R(S L+S M+S H)-R(B L+B M+B H)] / 3
$$

Where $R(S L+S M+S H)$ is the expected return on $(S L+S M+S H)$ portfolios, and $\mathrm{R}$ $(B L+B M+B H)$ is the expected return on $(B L+B M+B H)$ portfolios.

$\mathrm{HML}$ (high minus low) is the difference between returns on high (BE/ME) stocks portfolio and a portfolio of low (BE/ME) stocks, and is calculated by the following equation:

$$
H M L=[R(S H+B H)-R(S L+B L)] / 2
$$


Where $R(S H+B H)$ is the expected return on $(S H+B H)$ portfolios, and $R(S L+B L)$ is the expected return on $(S L+B L)$ portfolios.

To construct the herding factor $\left(h_{m t}\right)$, we will construct a portfolio created by the difference between the returns on the portfolio in which the herd behaviour is statistically significant $\left(R h m t_{1}\right)$, and the returns on the portfolio in which the herd behaviour is not statistically significant $\left(R h m t_{0}\right)$, as follows:

$$
h_{m t}=R h m t_{1-} R_{h m t_{0}}
$$

\section{The Model}

Fama and French (1993) developed the three-factor model to describe the relation between expected excess returns $\left[R_{i t}-R_{f}\right]$ and excess market return $\left(R_{M}-R_{F}\right)$ as well as the model including two additional factors related to the value risk factor (HML) and the size risk factor (SMB). We have added an additional risk factor to the three-factor model, called herding factor $\left(h_{m t}\right)$. To estimate the model parameters, the two-pass cross-sectional regression was used. The first step is to use the time-series regression of the excess return of the sample stocks on excess market return, HML, SMB and $h_{m t}$ by the following model:

$$
R_{i t}-R_{f}=a_{i}+b_{i}\left[R_{m t}-R_{f}\right]+s_{i}[S M B]+h_{i}[H M L]+\beta_{i}\left[h_{m t}\right]+\varepsilon_{i t}
$$

\section{Where:}

- $\quad R_{i t}$ is the expected return on stock $i$ at time $t$;

- $\quad R_{f}$ is the risk-free rate;

- $\quad R_{m t}-R_{f}$ is the expected excess return of the market portfolio at time $t_{\text {; }}$

- $\quad$ SMB is the expected return of the size factor (a proxy for company size);

- $\quad$ HML is the expected return on the book-to-market value factor (a proxy for company value);

- $\quad h_{m t}$ is the expected return on herding factor (a proxy for herding behaviour);

- $\quad b i, s i, h i, B_{i}$ are the coefficients (betas) of the independent variables;

- $a i$, cit are the intercept and the error term, respectively.

The second step is to run the cross-sectional regression, as follows:

$$
r_{i}=\gamma_{0}+\gamma_{1} b i+\gamma_{2} s i+\gamma_{3} h i+\gamma_{4} \beta_{i}+\varepsilon_{i t}
$$

Where:

- $\quad r i$ is the average excess return for the stock i over our full sample period;

- $\gamma_{0}, \gamma_{1}, \gamma_{2}, \gamma_{3}$ and $\gamma_{4}$ are the parameters that will be estimated;

- $\quad b i$ is the estimated coefficients of the expected excess return of the market portfolio;

- $\quad s i$ is the estimated coefficients of the size factor (SMB);

- $\quad h i$ is the estimated coefficients of the value factor $(\mathrm{HML})$;

- $\quad B_{i}$ is the estimated coefficients of the herding factor $\left(h_{m t}\right)$. 


\section{Empirical Results}

\subsection{Testing Herd Behaviour}

We divided the sample into two portfolios and tested the herd behaviour for each of them; Table 1 and Table 2 show the statistical tests of the tow portfolio.

Table 1 The Statistical Tests of the Portfolio in which the Herd Behaviour Is Statistically Significant

\begin{tabular}{lcccccc}
\hline & Coefficient & Std. Error & $\begin{array}{c}\mathbf{z}- \\
\text { Statistic }\end{array}$ & Prob. & Variable & Estimate \\
\hline \hline $\mathbf{C ( 1 )} \mathbf{\mu m}$ & -0.001 & 0.090 & -0.013 & 0.991 & $\boldsymbol{\mu m}$ & -0.001 \\
\hline $\mathbf{C ( 2 )} \mathbf{~ \mathbf { m t }}$ & -3.141 & 0.349 & -9.009 & 0.000 & $\boldsymbol{\sigma}_{\mathbf{m v}}$ & 0.208 \\
\hline $\mathbf{C ( 3 )} \mathbf{~} \mathbf{m}$ & 0.868 & 0.195 & 4.456 & 0.000 & $\boldsymbol{\varphi m}$ & 0.868 \\
\hline $\mathbf{C ( 4 )} \mathbf{n m t}$ & -5.542 & 1.936 & -2.862 & 0.004 & $\boldsymbol{\sigma}_{\mathbf{m n}}$ & 0.063 \\
\hline
\end{tabular}

Source: Author's construction

Table 1 shows the Herding space-state model for 18 stocks listed on the EGX from January 2014 to December 2018. Coefficient c(1) refers to $\mu \mathrm{m}$ of equation (1), and it is insignificant at the level of $5 \%$. Coefficient $c(2)$ corresponds to the error term of equation (1), the error term vmt was written in an exponential form in the spacestate model, to avoid negative values. Both $c(3)$ and $c(4)$ represent the persistence parameter $\left(\varphi_{\mathrm{m}}\right)$ as well as the standard deviation $\left(\sigma_{\mathrm{mn}}\right)$ of the state-equation error $\left(\eta_{\mathrm{mt}}\right)$, respectively. Both of them are statistically significant at $5 \%$ significance level, which confirms the presence of herd behaviour.

Table 2 shows the Herding space-state model for 32 stocks listed on the (EGX) from January 2014 to December 2018. The results show that both $c(3)$ and $c(4)$ represent the persistence parameter $(\varphi \mathrm{m})$ as well as the standard deviation ( $\sigma \mathrm{m \eta})$ of the state-equation error ( $\mathrm{nmt}$ ), respectively, and neither of them is statistically significant at $5 \%$ significance level, which confirms the absence of herd behaviour.

Table 2 The Statistical Tests of the Portfolio in which the Herd Behaviour Is Not Statistically significant

\begin{tabular}{lcccccc}
\hline & Coefficient & $\begin{array}{c}\text { Std. } \\
\text { Error }\end{array}$ & $\begin{array}{c}\mathbf{Z}- \\
\text { Statistic }\end{array}$ & Prob. & Variable & Estimate \\
\hline \hline $\mathbf{C ( 1 )} \mathbf{\mu m}$ & -0.148 & 0.019 & -7.595 & 0.0000 & $\boldsymbol{\mu m}$ & -0.148 \\
\hline $\mathbf{C ( 2 )} \mathbf{~ m \mathbf { m }}$ & -21.712 & $1.48 \mathrm{E}+10$ & $-1.47 \mathrm{E}-09$ & 1.0000 & $\boldsymbol{\sigma}_{\mathbf{m v}}$ & $1.92895 \mathrm{E}-05$ \\
\hline $\mathbf{C ( 3 )} \mathbf{~} \mathbf{m}$ & 0.023 & 8.687 & 0.003 & 0.9978 & $\mathbf{9 m}$ & 0.023 \\
\hline $\mathbf{C ( 4 )} \mathbf{n m t}$ & -4.215 & 373.308 & -0.011 & 0.9910 & $\boldsymbol{\sigma}_{\mathbf{m n}}$ & 0.122 \\
\hline
\end{tabular}

Source: Author's construction 


\subsection{Summary Descriptive Statistics}

Table 3 presents the descriptive statistics of the excess stock return, excess market portfolio return, size factor (SMB), and the value factor (HML).

Table 3 Descriptive Statistics of the Excess Stock Return, Excess Market Portfolio Return, Size Factor (SMB), Value Factor (HML) and Herding Behaviour Factor (hmt)

\begin{tabular}{llllll}
\hline & $\begin{array}{c}\mathbf{R}_{\mathbf{i t}}-\mathbf{R}_{\mathbf{f}} \\
\text { Excess stock } \\
\text { return }\end{array}$ & $\begin{array}{c}\mathbf{R}_{\mathbf{M}}-\mathbf{R}_{\mathbf{f}} \\
\text { Excess } \\
\text { market } \\
\text { return }\end{array}$ & HML & SMB & hmt \\
\hline \hline Mean & -0.079 & -0.078 & 0.001 & -0.005 & 0.005 \\
\hline Std. Error & 0.002 & 0.009 & 0.007 & 0.005 & 0.005 \\
\hline Median & -0.078 & -0.080 & 0.002 & -0.007 & 0.001 \\
\hline Std. Dev. & 0.013 & 0.070 & 0.051 & 0.040 & 0.041 \\
\hline Variance & 0.000 & 0.005 & 0.003 & 0.002 & 0.002 \\
\hline Kurtosis & 0.662 & 4.822 & 2.585 & 1.230 & 1.592 \\
\hline Skewness & 0.602 & 1.302 & 0.015 & 0.177 & 0.420 \\
\hline Minimum & -0.106 & -0.217 & -0.139 & -0.117 & 0.230 \\
\hline Maximum & -0.042 & 0.224 & 0.171 & 0.115 & -0.087 \\
\hline
\end{tabular}

Source: Author's construction

Where $\left(R_{i t}-R_{f}\right)$ is the excess stock return; $\left(\mathrm{R}_{\mathrm{mt}}-R_{f}\right)$ is the market portfolio excess return; SMB is the difference of returns on the portfolio consisting of small stocks and the portfolio consisting of big stocks per month; HML is the excess return of stocks with high BE/ME-ratio compared to stocks with low BE/ME-ratio per month.

The results in Table 3 show that the mean return of SMB factor is equal to $(-0.01)$. This indicates that the return on the portfolio consisting of big stocks outperforms the return on the portfolio consisting of small stocks. Also, the mean return of $\mathrm{HML}$ factor is equal to zero; this indicates that there is no difference between the return on the portfolio consisting of stocks with high BE/ME-ratio and the portfolio consisting of stocks with low BE/ME-ratio. This result is in conflict with the threefactor model, which states that the stocks with high book-to-market equity ratios (value stocks) have high returns compared to stocks with low book-to-market equity ratios (growth stocks) and small stocks have high returns compared to big stocks. The results also show that the mean return of $\left(R_{i t}-R_{f}\right)$ and $\left(\mathrm{R}_{\mathrm{mt}}-R_{f}\right)$ equals to $(-0.08)$, which may be due to the political fluctuations the country witnessed during the study period and which led to successive losses for the stock market. Finally, the mean return of herding factor $\left(h_{m t}\right)$ equals to $(0.00502)$, indicating a slight superiority of the portfolio in which the herding behaviour is statistically 
significant compared to the returns on the portfolio in which the herd behaviour is not statistically significant.

\subsection{Testing the Three-factor Model}

Table 4 shows the regression results of the Fama and French three-factor model in the EGX from January 2014 to December 2018.

Table 4 Regression Results of the Fama and French Three-factor Model

\begin{tabular}{|c|c|c|c|c|c|c|c|}
\hline Model & $\begin{array}{l}\text { Sum of } \\
\text { Squares }\end{array}$ & df & $\begin{array}{l}\text { Mean } \\
\text { Square }\end{array}$ & $\mathbf{F}$ & Sig. & $\mathbf{R}$ & $\begin{array}{l}\text { Adjusted } \\
\text { R Square }\end{array}$ \\
\hline Regression & 0.000 & 3 & 0 & \multirow{3}{*}{1.017} & \multirow{3}{*}{0.394} & \multirow{3}{*}{0.249} & \multirow{3}{*}{0.001} \\
\hline Residual & 0.007 & 46 & 0 & & & & \\
\hline Total & 0.008 & 49 & & & & & \\
\hline \multicolumn{8}{|c|}{ Coefficients } \\
\hline & & \multicolumn{2}{|c|}{$\begin{array}{l}\text { Unstandardize } \\
\text { d Coefficients }\end{array}$} & $\begin{array}{l}\text { Standardized } \\
\text { Coefficients }\end{array}$ & \multirow{2}{*}{$\mathbf{t}$} & & \multirow{2}{*}{ Sig. } \\
\hline & & B & $\begin{array}{l}\text { Std. } \\
\text { Error }\end{array}$ & Beta & & & \\
\hline \multicolumn{2}{|c|}{ (Constant) } & -0.085 & 0.008 & & -10.356 & \multicolumn{2}{|r|}{0} \\
\hline \multicolumn{2}{|c|}{$\mathrm{Rm}-\mathrm{Rf}$} & 0.010 & 0.008 & 0.138 & 0.889 & \multicolumn{2}{|r|}{0.379} \\
\hline \multicolumn{2}{|c|}{ SMB } & 0.000 & 0.003 & -0.201 & -1.387 & \multicolumn{2}{|r|}{0.172} \\
\hline \multicolumn{2}{|c|}{ HML } & 0.000 & 0.003 & 0.046 & 0.297 & \multicolumn{2}{|r|}{0.768} \\
\hline
\end{tabular}

Source: Author's construction

The results show that the Adjusted $\mathrm{R}$ Square is equal to $0.1 \%$, which indicates that the explanatory power of the risk coefficients in the three-factor model is very weak. The intercept is significant and negative; if the intercept is negative, the returns on assets are lower than it should have given its risk level; therefore, there is a pricing error in the specifications of the model, where the intercept should be equal to zero. The slope of the market premium (beta) is not significant and is positive with t-statistics equal to $(0.889)$, so the market risk premium is not a determinant of the required rate of return for stocks. The SMB coefficient is not significant and is equal to zero with t-statistics equal to $(-1.387)$, which provides evidence of the absence of the small firm effect. Moreover, the HML coefficient is not significant and is equal to zero with t-statistics equal to (0.297), which confirms that the book-to-market ratio effect does not exist in the market. The results indicate that the Fama and French three-factor model cannot explain excess stock returns in the EGX. These results contradict the findings of Shaker and Elgiziry (2014), Shaker and Abdeldayem (2018), and Ragab et al. (2019), who supported the Fama and French three-factor model (1993) in the EGX. Our results do not support the Fama and French three-factor model (1993). 


\subsection{Testing the impact of herding on the risk pricing}

Table 5 shows the regression results after adding an additional risk factor reflecting herding behaviour $\left(h_{m t}\right)$ to the three-factor model of Fama and French from January 2014 to December 2018 in the EGX.

Table 5 Regression Results of the Fama and French Three-factor Model After Adding the Herding Behaviour Factor

\begin{tabular}{|c|c|c|c|c|c|c|c|}
\hline Model & $\begin{array}{l}\text { Sum of } \\
\text { Squares }\end{array}$ & df & $\begin{array}{l}\text { Mean } \\
\text { Square }\end{array}$ & $\mathbf{F}$ & Sig. & $\mathbf{R}$ & $\begin{array}{l}\text { Adjusted } \\
\text { R Square }\end{array}$ \\
\hline Regression & 0.001 & 4 & 0 & \multirow{3}{*}{1.064} & \multirow{3}{*}{0.386} & \multirow{3}{*}{0.294} & \multirow{3}{*}{0.005} \\
\hline Residual & 0.007 & 45 & 0 & & & & \\
\hline Total & 0.008 & 49 & & & & & \\
\hline \multicolumn{8}{|c|}{ Coefficients } \\
\hline & & \multicolumn{2}{|c|}{$\begin{array}{c}\text { Unstandardized } \\
\text { Coefficients }\end{array}$} & $\begin{array}{c}\text { Standardized } \\
\text { Coefficients }\end{array}$ & \multirow{2}{*}{$\mathbf{t}$} & \multirow{2}{*}{\multicolumn{2}{|c|}{ Sig. }} \\
\hline & & B & $\begin{array}{l}\text { Std. } \\
\text { Error }\end{array}$ & Beta & & & \\
\hline \multicolumn{2}{|c|}{ (Constant) } & -0.086 & 0.008 & & -10.434 & \multicolumn{2}{|r|}{0.000} \\
\hline \multicolumn{2}{|c|}{$\mathrm{Rm}-\mathrm{Rf}$} & 0.010 & 0.008 & 0.925 & 0.999 & \multicolumn{2}{|r|}{0.323} \\
\hline \multicolumn{2}{|c|}{ SMB } & 0.000 & 0.003 & -0.192 & -1.329 & \multicolumn{2}{|r|}{0.191} \\
\hline \multicolumn{2}{|c|}{ HML } & 0.000 & 0.003 & 0.018 & 0.115 & \multicolumn{2}{|r|}{0.909} \\
\hline \multicolumn{2}{|c|}{$\mathrm{hmt}$} & -0.006 & 0.007 & -0.785 & -0.841 & & 0.405 \\
\hline
\end{tabular}

Source: Author's construction

The results show that the Adjusted $\mathrm{R}$ Square is equal to $0.005 \%$, which indicates that the explanatory power of the risk coefficients in the model is very weak. The intercept is significant and negative; whereas the intercept should be equal to zero. The slope of the market premium (beta) is not significant and is positive with a t-statistics equal to (0.999), so the market risk premium is not a determinant of the required rate of return for stocks. The SMB coefficient is not significant and is equal to zero with t-statistics equal to $(-1.329)$, which provides evidence of the absence of the small firm effect. Moreover, the HML coefficient is not significant and is equal to zero with t-statistics equal to $(0.115)$, which confirms that the book-to-market ratio effect does not exist in the market. The $\left(h_{m t}\right)$ coefficient is not significant and is negative with t-statistics equal to $(-0.841)$, therefore, the results do not support the Fama and French model after adding the herding behaviour factor, i.e., there is no effect of herding behaviour on the risk pricing in the Egyptian Stock Exchange. Also, the results are not consistent with the findings of Messis and Zapranis (2014), in which they concluded that herding behaviour can be regarded as an additional risk factor. 


\section{Conclusions}

The study examined the impact of herding behaviour on the risk pricing in the Egyptian Stock Exchange by adding an additional risk factor reflecting herding behaviour to the Fama and French three-factor model, using a sample of 50 stocks listed on the EGX from January 2014 to December 2018. At first, we investigated the validity of the Fama and French three-factor model in its original form by using monthly data for a sample of 50 firms listed on the Egyptian Stock Exchange from January 2014 to December 2018. The study used the same methodology of Fama and French (1993) to construct six portfolios (SL, SM, SH, BL, BM, BH) based on the intersection of the tow size and three BE/ME portfolios. And then we re-tested the Fama and French three-factor model after adding the additional risk factor, in order to detect the effect of herding on the risk pricing in the EGX. To construct the herding factor $\left(h_{m t}\right)$, we constructed a portfolio created by the difference between the returns on the portfolio in which the herd behaviour is statistically significant (Rhmt1), which consisted of 18 stocks, and the returns on the portfolio in which the herd behaviour is not statistically significant (Rhmt0), which consisted of 32 stocks. The study used the same methodology as developed by Hwang and Salmon (2004), who used the state-space model and using Kalman's filter to measure herd behaviour. Based on our statistical results, this study found that the Fama and French three-factor model cannot explain excess stock returns in its original form and after adding the herd behaviour factor as an additional risk factor, i.e., the beta, HML, SMB factors are not appropriate in evaluating the relationship between risk and return, and there is no effect of herding behaviour on the expected return in the Egyptian Stock Exchange. The political and economic fluctuations that Egypt witnessed are perhaps the most appropriate explanation for why the Fama and French three-factor model (1993) does not show statistical significance in its original form and after adding the herd behaviour factor as an additional risk factor, as these fluctuations began after the January revolution in 2011, which witnessed a change of the political system in Egypt, and extended to include most of the study periods. They are considered one of the most important factors that negatively affected the performance of the Egyptian stock market.

Our research is of interest to all researchers and investors. Researchers may retest the proposed model in different financial markets, where they may obtain better results in explaining the relationship between return and risk. Additionally, investors should be concerned to know anomalies that could affect the returns of their investments.

\section{References}

Ariel, R. A. (1987). A monthly effect in stock returns. Journal of Financial Economics, 18(1), pp. 161-174.

Banz, R. W. (1981). The relationship between return and market value of common stocks. Journal of Financial Economics, 9(1), pp. 3-18. 
Basu, S. (1983). The relationship between earnings' yield, market value and return for NYSE common stocks: Further evidence. Journal of Financial Economics, 12(1), pp. 129-156.

Bikhchandani, S. and Sharma, S. (2001). Herd behavior in financial markets. IMF Staff papers, 47(3), pp. 279-310.

Black, F. (1972). Capital market equilibrium with restricted borrowing. The Journal of Business, 45(3), pp. 444-455.

Black, F., Jensen, M. C. and Scholes, M. (1972). The capital asset pricing model: Some empirical tests. Studies in the theory of capital markets, 81(3), pp. 79-121.

Chang, E. C., Cheng, J. W. and Khorana, A. (2000). An examination of herd behavior in equity markets: An international perspective. Journal of Banking \& Finance, 24(10), pp. 1651-1679.

Christie, W. G. and Huang, R. D. (1995). Following the pied piper: Do individual returns herd around the market? Financial Analysts Journal, 51(4), pp.31-37.

De Bondt, W., and Thaler, R. (1985). Does the stock market overreact? Journal of Finance, 40(3), pp. 793-805.

Demir, N., Mahmud, S. F., and Solakoglu, M. N. (2014). Sentiment and beta herding in the Borsa İstanbul (BIST). Risk Management Post-financial Crisis: A Period of Monetary Easing, 96, pp. 389-400.

Demirer, R., Kutan, A. M. and Chen, C. D. (2010). Do investors herd in emerging stock markets? Evidence from the Taiwanese market. Journal of Economic Behavior \& Organization, 76(2), pp. 283-295.

Dolinar, D. (2013). Test of the Fama-French three-factor model in Croatia. UTMS Journal of Economics, 4(2), pp. 101-112.

Elkhaldi, A. and Benabdelfatteh, Y. (2014). Testing Herding Effects on Financial Assets Pricing: The Case of the Tunisian Stock Market. British Journal of Economics, Management and Trade, 4(7), pp. 1046-1059.

Eraslan, V. (2013). Fama and french three-factor model: Evidence from Istanbul stock exchange. Business and Economics Research Journal, 4(2), pp. 11- 22.

Fama, E. F. (1965). Random Walks in Stock Market Prices. Financial Analysts Journal, 21(5), pp. 55-59.

Fama, E. F. and French, K. R. (1992). The cross-section of expected stock returns. The Journal of Finance, 47(2), pp. 427-465.

Fama, E. F. and French, K. R. (1993). Common risk factors in the returns on bonds and stocks. Journal of Financial Economics, 33, pp. 3-56.

Fama, E. F. and MacBeth, J. D. (1973). Risk, return, and equilibrium: Empirical tests. Journal of Political Economy, 81(3), pp. 607-636. 
French, K. (1980). Stock returns and the weekend effect. Journal of Financial Economics, 8, pp. 55-69.

Güvercin, A. (2016). Sentimental herding: The role of regional and global shocks in Egyptian and Saudi stock markets. Sosyoekonomi, 24(27), pp. 25-32.

Hwang, S. and Salmon, M. (2004). Market stress and herding. Journal of Empirical Finance, 11(4), pp. 585-616.

Jensen, M. C. (1978). Some anomalous evidence regarding market efficiency. Journal of Financial Economics, 6(2/3), pp. 95-101

Lakonishok, J. and Smidt, S. (1988). Are seasonal anomalies real? A ninety-year perspective. The Review of Financial Studies, 1(4), pp. 403-425

Lintner, J. (1965). The valuation of risk assets and selection of risky investments in stock portfolios and capital budgets. Review of Economics and Statistics, 47, pp. 13-37.

Markowitz, H. (1952). Portfolio selection. The Journal of Finance, 7(1), pp. 77-91.

Messis, P. and Zapranis, A. (2014). Herding behaviour and volatility in the Athens Stock Exchange. The Journal of Risk Finance, 15 (5), pp. 572-590.

Mertzanis, C. and Allam, N. (2018). Political Instability and Herding Behaviour: Evidence from Egypt's Stock Market. Journal of Emerging Market Finance, 17(1), 29-59.

Metwally, A. H., Eldomiaty, T. and Abdel-Wahab, L. A. (2016). Does herding behaviour vary in bull and bear markets? Perspectives from Egypt. International Journal of Behavioural Accounting and Finance, 6(1), pp. 26-53.

Nartea, G. V., Ward, B. D. and Djajadikerta, H. G. (2009). Size, BM, and momentum effects and the robustness of the Fama-French three-factor model: Evidence from New Zealand. International Journal of Managerial Finance, 5(2), pp. 179-200.

Ragab, N. S., Abdou, R. K. and Sakr, A. M. (2019). A Comparative Study between the Fama and French Three-Factor Model and the Fama and French Five-Factor Model: Evidence from the Egyptian Stock Market. International Journal of Economics and Finance, 12(1), pp.52-69.

Rahmani, F. M. and Salmani, J. Z. (2010). Tests of the Fama and French Three Factor Model in Iran. Iranian Economic Review, 15(27), pp. 117-132.

Ross, S. (1976). Arbitrage Theory of Capital Asset Pricing. Journal of Economic Theory, 13(3), pp. 341-360.

Rozeff, M. S. and Kinney Jr, W. R. (1976). Capital market seasonality: The case of stock returns. Journal of Financial Economics, 3(4), pp. 379-402. 
Shaker, M. A. and Abdeldayem, M. M. (2018). Examining asset pricing models in emerging markets: Evidence from Egypt. Corporate Ownership and Control, 16(1), 50-57.

Shaker, M. A. and Elgiziry, K. (2014). Comparisons of Asset Pricing Models in the Egyptian Stock Market. Accounting and Finance Research, 3(4).

Sharpe, W. F. (1964). Capital asset prices: A theory of market equilibrium under conditions of risk. The Journal of Finance, 19(3), pp. 425-442.

Shefrin. H. and Statman. M. (1985). The disposition to sell winners too early and ride losers too long: Theory and evidence. Journal of Finance, 40 (3), pp. 777-790.

Shiller, R. (1980). Do Stock Prices Move Too Much to Be Justified by Subsequent Changes in Dividends? American Economic Review, 71(3), pp. 421-435.

Simlai, P. (2009). Stock returns, size, and book-to-market equity. Studies in Economics and Finance, 26(3), 198-212. doi:10.1108/10867370910974026

Sobti, N. (2016). Revisting Capm and Fama French Three Factor Model in Indian Equity Market. Business Analyst, ISSN 0973-211X, 37(1), pp. 31-46.

Taneja, Y. P. (2010). Revisiting fama french three-factor model in indian stock market. Vision, 14(4), pp. 267-274.

Wang, W. G. (2018). The Variation of Fama-French Three-Factor Beta Risks by Interval Test in Taiwan Stock Market: Theory and Evidence. International Research Journal of Finance and Economics, 165, pp. 90-109. 